\title{
Associations between North Pacific right whales and their zooplanktonic prey in the southeastern Bering Sea
}

\author{
Mark F. Baumgartner ${ }^{1, *}$, Nadine S. J. Lysiak ${ }^{1}$, H. Carter Esch ${ }^{1}$, \\ Alexandre N. Zerbini ${ }^{2}$, Catherine L. Berchok ${ }^{2}$, Phillip J. Clapham ${ }^{2}$ \\ ${ }^{1}$ Biology Department, Woods Hole Oceanographic Institution, 266 Woods Hole Road, MS \#33, Woods Hole, \\ Massachusetts 02543, USA \\ ${ }^{2}$ National Marine Mammal Laboratory, Alaska Fisheries Science Center, 7600 Sand Point Way NE, Seattle, \\ Washington 98115, USA
}

\begin{abstract}
Due to the seriously endangered status of North Pacific right whales Eubalaena japonica, an improved understanding of the environmental factors that influence the species' distribution and occurrence is needed to better assess the effects of climate change and industrial activities on the population. Associations among right whales, zooplankton, and the physical environment were examined in the southeastern Bering Sea during the summers of 2008 and 2009. Sampling with nets, an optical plankton counter, and a video plankton recorder in proximity to whales as well as along cross-isobath surveys indicated that the copepod Calanus marshallae is the primary prey of right whales in this region. Acoustic detections of right whales from sonobuoys deployed during the cross-isobath surveys were strongly associated with $C$. marshallae abundance, and peak abundance estimates of $C$. marshallae in $2.5 \mathrm{~m}$ depth strata near a tagged right whale ranged as high as $10^{6}$ copepods $\mathrm{m}^{-3}$. The smaller Pseudocalanus spp. was higher in abundance than C. marshallae in proximity to right whales, but significantly lower in biomass. High concentrations of $C$. marshallae occurred in both the surface and bottom layers of the highly stratified water column, but there was no evidence of diel vertical migration. Instead, occurrence of C. marshallae in the bottom layer was associated with elevated near-bottom light attenuance and chlorophyll fluorescence, suggesting C. marshallae may aggregate at depth while feeding on resuspended phytodetritus. Despite the occasional presence of strong horizontal gradients in hydrographic properties, no association was found between $C$. marshallae and either fronts or phytoplankton distribution.
\end{abstract}

KEY WORDS: Eubalaena japonica · Right whale $\cdot$ Calanus marshallae Calanus glacialis · Bering Sea $\cdot$ Baleen whale $\cdot$ Resuspension $\cdot$ Phytodetritus

Resale or republication not permitted without written consent of the publisher

\section{INTRODUCTION}

North Pacific right whales Eubalaena japonica were once abundant throughout the eastern North Pacific and Bering Sea over the continental shelf, slope, and abyssal plain (Clapham et al. 2004, Shelden et al. 2005, Josephson et al. 2008) but were nearly extirpated by whaling during the 19th and early 20th centuries. Brownell et al. (2001) suggested that the right whale population was growing by the mid 20th century, but large illegal catches by Soviet whalers during the 1960s in the eastern North Pacific and Bering Sea (Doroshenko 2000, Ivashchenko \& Clapham 2012) probably crippled recovery. Modern sightings and acoustic detections confirm that the southeastern Bering Sea remains an important area 
for right whales from late spring to late fall (Shelden et al. 2005, Munger et al. 2008). Based on both photographic and genetic mark-recapture analyses, however, Wade et al. (2011a) estimated that the population occurring in the Bering Sea is comprised of only about 30 individuals. Despite their critically endangered status, our understanding of the behavioral and environmental factors that govern North Pacific right whale distribution is quite poor; therefore, assessing potential impacts of climate change and human activities on this remnant population is difficult.

Right whales are ram filter feeders and are very limited in the type of prey that they can consume. Their slow swimming speed and large filtering apparatus precludes capture of the fish and very large euphausiids that are preyed upon by the rorquals (e.g. humpback whales Megaptera novaeangliae, blue whales Balaenoptera musculus, and fin whales Balaenoptera physalus). Instead, right whales feed primarily on calanoid copepods and small euphausiids. Examination of stomach contents from whales killed by Japanese whalers have indicated that North Pacific right whales feed on the copepods Calanus marshallae, Metridia spp., and Neocalanus spp., and on the euphausiid Euphausia pacifica (Omura 1986). Neocalanus plumchrus was found in the stomachs of right whales killed in the deep waters of the eastern North Pacific (near southern Kodiak Island), and $N$. cristatus was found in the stomachs of whales killed just off the southeastern Bering Sea continental shelf (i.e. over the slope and abyssal plain). Zooplankton net samples collected by Tynan et al. (2001) near right whales in the middle shelf domain of the southeastern Bering Sea (between the 50 and $100 \mathrm{~m}$ isobaths) were dominated by C. marshallae.

Studies of North Atlantic right whales Eubalaena glacialis have demonstrated that the single most important habitat feature for this species is the occurrence of concentrated patches of prey (Mayo \& Marx 1990, Wishner et al. 1995, Baumgartner et al. 2003a), and we anticipate that the same is true of North Pacific right whales. Copepods must be highly concentrated for right whales to feed efficiently, but the processes that form and maintain these concentrated patches are not well understood. Physical processes that cause horizontal aggregation of copepods are likely important to right whales, such as fronts (Brown \& Winn 1989, Wishner et al. 1995) or gyrelike circulation (Baumgartner et al. 2003a), but the interactions between copepod behavior and physical processes that cause vertical aggregation are equally important (e.g. copepod diapause and bottom mixed layer dynamics; Baumgartner \& Mate 2003). With the exception of a few zooplankton tows conducted near right whales in the southeastern Bering Sea (Tynan et al. 2001), no research has been conducted on the relationship between North Pacific right whales and their zooplanktonic prey or the oceanographic processes that concentrate those prey.

The present study was designed to address 5 questions: (Q1) what is the primary prey of North Pacific right whales in the southeastern Bering Sea, (Q2) does the primary zooplanktonic prey species undergo diel vertical migration, and if so, how does this phenomenon influence the behavior or occurrence of right whales, (Q3) what are the spatial relationships among right whale presence, prey distribution, and environmental conditions, (Q4) how does the vertical distribution of zooplankton influence the diving and foraging behavior of right whales, and (Q5) what oceanographic processes are responsible for creating concentrated zooplankton patches upon which right whales feed in the southeastern Bering Sea? Based on complementary studies of North Atlantic right whales, we hypothesize that North Pacific right whales feed on the most lipidrich calanoid copepod species available in the middle shelf domain of the Bering Sea (Mayo \& Marx 1990, Wishner et al. 1995, Baumgartner et al. 2003a), and that the spatial distribution of the whales is closely associated with that of their zooplanktonic prey (Baumgartner et al. 2003a). We further hypothesize that prey will be organized in vertically compressed thin layers to which the whales will repeatedly dive while foraging (Baumgartner \& Mate 2003), and that the depth of these layers could change on a diel schedule (Baumgartner et al. 2011) or could remain fixed if the whale's copepod prey are dormant (Baumgartner et al. 2003b). Finally, we address the hypothesis that right whales feed on zooplankton that are aggregated by ocean fronts on the southeastern Bering Sea shelf.

\section{MATERIALS AND METHODS}

\section{Cruises}

While their exceedingly low population size makes eastern North Pacific right whales a high priority for research and conservation, it also makes them a challenge to find and study. We participated in cruises to the southeastern Bering Sea aboard the FV 'Ocean Olympic' during early August 2008 and aboard the FV 'Aquila' during late July and early 
August 2009 (Fig. 1). Remarkably, right whales were located shortly after our arrival in the study area each year (during the summer before our study, a dedicated 6 wk cruise to the southeastern Bering Sea was unable to locate a single right whale, and during the summer after our study, right whales were acoustically detected in the region but poor weather allowed visual contact on only $1 \mathrm{~d}$ of a dedicated $26 \mathrm{~d}$ cruise). To address the questions and hypotheses posed above, we (1) sampled the zooplankton community in the presence and absence of right whales to identify their primary prey (Q1), (2) repeatedly sampled oceanographic conditions, prey vertical distribution, and acoustically derived whale occurrence at drifting stations to characterize temporal variability in environmental conditions that may influence right whale occurrence and behavior (Q2), (3) conducted cross-isobath oceanographic and passive acoustic surveys to examine the spatial relationships among right whale presence, prey distribution, and environmental conditions (Q3), and (4) attached short-term tags to right whales to characterize their diving and foraging behavior (Q4). Results of these 4 activities are reported here (Table 1). Additional cruise activities involving right whales included satellite tagging (A. N. Zerbini unpubl. data), photographic identification (Kennedy et al. 2012), and more extensive passive acoustic monitoring (Berchok et al. 2009); results of these activities are reported elsewhere.

\section{Profiling instrument package}

Environmental sampling was conducted with a profiling instrument package consisting of a conductivity-temperature-depth instrument (CTD) (SBE 19plus, Seabird Electronics), chlorophyll fluorometer (Wetstar WS3S, Wetlabs), optical plankton counter (OPC) (OPC-1T, Focal Technologies; Herman 1988, 1992), video plankton recorder (VPR) (DAVPR, Seascan; Davis et al. 1992, 1996), altimeter (PSA-916,

Fig. 1. Eubalaena japonica. (a) Southeastern Bering Sea with federally designated North Pacific right whale critical habitat outlined in red. Study area is outlined in black; stars indicate locations of net tows collected outside of the study area in 2008. (b,c) Locations of cross-isobath transect stations (triangles), drifting stations (large light blue circle encompasses all cast locations), net tows (stars), right whale sightings (squares), and sonobuoy deployments (filled and open small circles indicate where right whales were and were not acoustically detected, respectively) during (b) 5 to 13 August 2008 and (c) 22 July to 3 August 2009
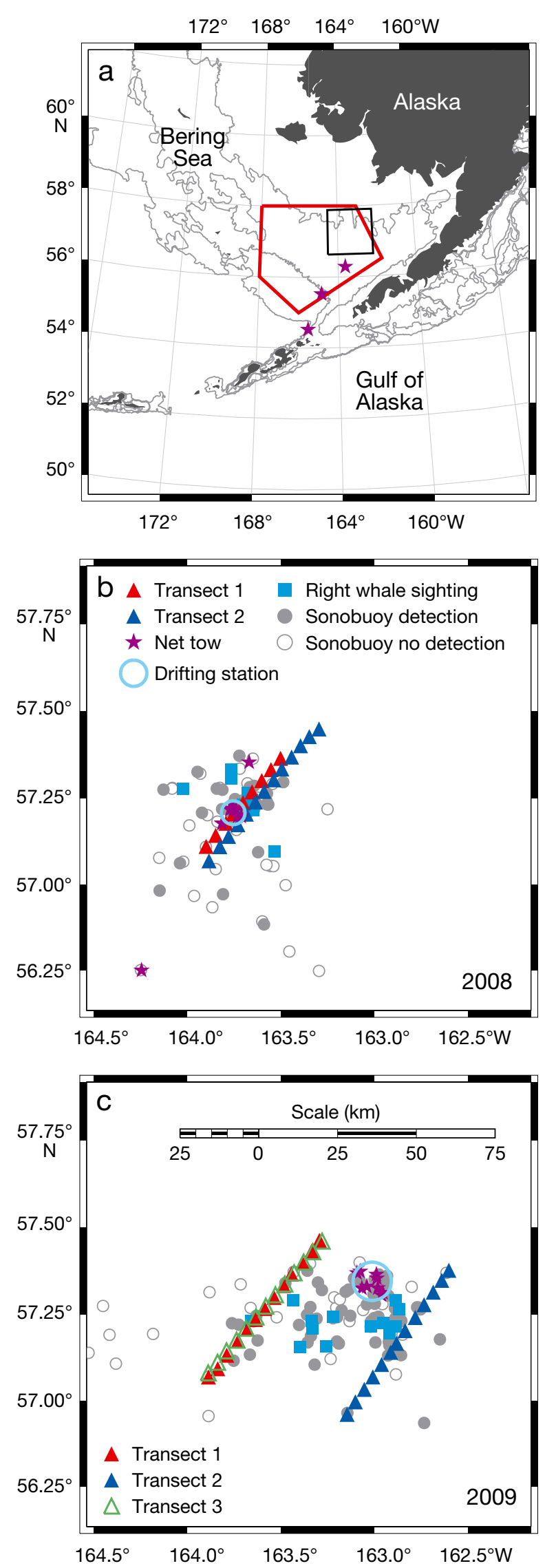
Table 1. Dates, times, duration, and number of casts conducted with the vertical profiling instrument package for each study activity. All times are local

\begin{tabular}{|lcccc|}
\hline Activity & \multicolumn{1}{c}{ Start } & End & Duration (h) & No. casts \\
\hline $\mathbf{2 0 0 8}$ & & & & \\
Transect 1 & Aug 06 13:24 & Aug 06 17:42 & 4.3 & 9 \\
Drifting station & Aug 06 21:25 & Aug 07 09:58 & 12.6 & 26 \\
Transect 2 & Aug 12 10:35 & Aug 12 15:05 & 4.5 & 13 \\
$\mathbf{2 0 0 9}$ & & & & \\
Transect 1 & Jul 23 10:59 & Jul 23 16:41 & 5.7 & 13 \\
Transect 2 & Jul 24 20:29 & Jul 25 02:18 & 5.8 & 13 \\
Drifting station & Jul 27 15:06 & Jul 28 14:32 & 23.4 & $49^{\text {a }}$ \\
Tagged whale & Jul 31 12:09 & Jul 31 12:31 & 0.4 & $3^{\text {a }}$ \\
Transect 3 & Aug 01 18:37 & Aug 01 23:34 & 5.0 & $13^{\text {a }}$ \\
aNo video plankton recorder (VPR) data available & & \\
\hline
\end{tabular}

Benthos), and a bottom contact switch (WHOI custom built). These instruments provided vertical profiles of temperature (CTD), salinity (CTD), chlorophyll fluorescence (fluorometer), particle size and abundance (OPC), light attenuance (OPC), and zooplankton abundance and community composition (VPR). The very strong thermocline observed in 2009 caused errors in the derivation of salinity from measured conductivity (owing to the different time constants of the SBE 19plus temperature and conductivity sensors); therefore, salinity was linearly interpolated between 10 and $24 \mathrm{~m}$ depth for all casts in 2009.

Independent estimates of Calanus marshallae abundance were obtained from the OPC and VPR after conducting an empirical calibration procedure using collocated zooplankton net samples (see below). The OPC counts and estimates the size of all particles that pass through its $2 \times 25 \mathrm{~cm}$ rectangular tunnel. Since we anticipated that no other zooplankton would be similarly sized and as abundant as $C$. marshallae in our study area, the abundance of particles in a particular size range should be strongly related to the abundance of C. marshallae (after Heath et al. 1999, Baumgartner 2003). Hence, after an appropriate calibration to determine the optimum particle size range, the abundance of $C$. marshallae could be accurately predicted using OPC particle abundance. Note that we refer here to the copepod of the Calanidae family found in our study area as $C$. marshallae, but we recognize that there is some taxonomic confusion at present between this species and C. glacialis in the eastern Bering Sea (R. Campbell pers. comm.).

Whereas the OPC can provide taxonomic discrimination only by inference based on particle size, the VPR collects images of a relatively small volume of water at high sample rates (23 to 30 images $\mathrm{s}^{-1}$ ) that can be used to unequivocally identify zooplankton. During 2008 and 2009, the VPR camera imaged a volume of approximately $12 \mathrm{ml}(17 \times 13 \times 54 \mathrm{~mm})$ and $2.2 \mathrm{ml}$ $(10 \times 7 \times 31 \mathrm{~mm})$, respectively, producing 10-bit $1392 \times 1024$ pixel digital images. Regions of interest, defined as areas in the images with high brightness and contrast, were automatically extracted using Auto Deck software (Seascan) and visually inspected to identify and classify zooplankton. Prosome length was measured for all copepods imaged by the VPR using custom software written in IDL, a scientific programming environment (ITT Visual Information Solutions). Each copepod's orientation angle relative to the depth of field was estimated so that the prosome length could be transformed from the image's coordinate system to one in which the copepod is laterally exposed (i.e. laying flat on its side). The abundance of Calanus marshallae was calculated as the number of copepods identified in the VPR images during the downcast that had prosome lengths of 1.5 to $3.5 \mathrm{~mm}$ divided by the product of the image volume and the total number of images captured during the downcast. The VPR catastrophically failed during the 2009 cruise on July 26, so no VPR data were available after that date (i.e. for the 2009 drifting station, tagging event, Transect 3, or net-VPR comparisons; see Table 1).

\section{Sonobuoys}

We deployed 2 types of sonobuoys to conduct passive acoustic monitoring in real time: 53E (Sparton, Hermes, and Undersea Sensor Systems) and $77 \mathrm{C}$ (Sparton). These sonobuoys transmitted audio to the ship via a VHF radio link, where it was digitized, recorded to hard disk, and simultaneously monitored in real time. The radio reception range was 10 to 15 miles, and the sonobuoys were programmed to transmit audio for up to $8 \mathrm{~h}$. An analyst reviewed all sonobuoy recordings for right whale calls, including gunshots and frequencymodulated sweeps. For the analyses below, sonobuoy deployments were categorized as those dur- 
ing which one or more right whale calls were detected, and those during which no right whale calls were detected.

\section{Zooplankton sampling}

Zooplankton samples were collected with a $75 \mathrm{~cm}$ diameter single ring and a $60 \mathrm{~cm}$ diameter double ring outfitted with $150 \mu \mathrm{m}$ mesh nets and a cod end. Two types of tows were conducted: oblique tows with the double ring net that spanned the entire water column and vertical hauls with the single ring net that spanned only the upper 10 to $15 \mathrm{~m}$. For oblique tows in 2008 and both oblique tows and vertical hauls in 2009, a flowmeter (2030R, General Oceanics) was suspended in the center of the net mouth to facilitate estimation of the volume filtered by the net. For vertical hauls in 2008, no flowmeter was used and filtered volume was estimated as the product of the net mouth area and the sampled depth stratum. A real-time telemetering instrument measuring temperature and depth (SBE39, Seabird Electronics) was affixed to the sea cable $1 \mathrm{~m}$ above the net for all oblique hauls so that the net could be fished to within $5 \mathrm{~m}$ of the sea floor. Large jellyfish were carefully rinsed and removed from the zooplankton samples prior to preservation in a buffered $5 \%$ formalin and seawater solution. Aliquots of the samples were obtained using the Huntsman Marine Laboratory beaker technique (Van Guelpen et al. 1982) and all organisms were identified to the lowest taxonomic level possible. All copepodids of Calanus were identified to developmental stage. Copepod biomass was estimated for Pseudocalanus spp. and Calanus marshallae by assuming all copepodids were in Stage C5, and individual dry weights were as follows: $8.5 \mu \mathrm{g}$ for Pseudocalanus spp. (Vidal \& Smith 1986, Liu \& Hopcroft 2008) and $327 \mu \mathrm{g}$ for C. marshallae (Vidal \& Smith 1986).

\section{OPC and VPR calibration}

The optimum OPC particle size range for predicting the abundance of late-stage Calanus marshallae was estimated using collocated OPC casts and net tows collected in 2008 and 2009 after Heath et al. (1999) and Baumgartner (2003). Particle sizes are expressed here in units of equivalent circular diameter, which is the diameter of a circle that has the same area as the illuminated cross-section of the particle. OPC-derived particle abundances were calculated over numerous size ranges by systematically varying both the minimum particle size $(0.25$ to $5.0 \mathrm{~mm}$ in $0.05 \mathrm{~mm}$ steps) and the span (0.10 to $3.0 \mathrm{~mm}$ in $0.05 \mathrm{~mm}$ steps) of the size range. Using only data from 2008 (the calibration dataset), the logarithm of these particle abundances was linearly regressed against the corresponding log-transformed net abundances of $C$. marshallae for each particle size range. The resulting regression equations were used to predict log-transformed C. marshallae abundance for the net tows conducted in 2009 (the validation dataset), and the root mean square error (RMSE) of these predictions was used to measure the prediction accuracy of the regression equations. The optimum size range was selected as that which simultaneously minimized the RMSE for the 2009 validation dataset and maximized the coefficient of determination $\left(\mathrm{r}^{2}\right)$ for the 2008 calibration dataset. A final calibration regression equation was determined using log-transformed net abundances of C. marshallae and log-transformed OPC particle counts in the optimum size range. At stations where both the VPR and a net tow were conducted, the VPR-derived abundance of $C$. marshallae was also compared to the corresponding net-derived abundance of $C$. marshallae using linear regression. Because a 1:1 relationship was not found, all VPRderived C. marshallae abundances were adjusted using this linear regression equation. As a final check, OPC- and VPR-derived C. marshallae abundances were compared for all casts without collocated net tows (i.e. for those stations not used in the calibration procedure).

\section{Drifting stations}

Once during each cruise we established a station in an area where right whales had been encountered within the past $24 \mathrm{~h}$ to monitor zooplankton vertical distribution over time. Right whales were acoustically monitored using sonobuoys and an array of 4 drifting buoys that each carried a hydrophone (HTI96-MIN, High Tech), passive acoustic recorder (Dell PocketPC running Loggerhead LARS-HF software), radio modem (FGR-series $900-\mathrm{MHz}$, Freewave), and a GPS receiver (GPS16 HVS, Garmin) (for details of the buoys, see Baumgartner et al. 2008). Every $2 \mathrm{~s}$, the buoys transmitted their GPS-derived location to a computer on the ship where the buoy and ship locations were graphically displayed. The buoys were deployed $3.7 \mathrm{~km}$ to the north, south, east and west of the initial station and were allowed to freely drift. 
Every half hour over the course of the next 12.6 (2008) or 23.4 (2009) h, a new station would be established in the center of the drifting buoy array, and a cast would be conducted at that station with the profiling instrument package. At roughly 3 (2008) or $6 \mathrm{~h}$ (2009) intervals, a zooplankton sample was collected in the surface mixed layer ( 0 to $10 \mathrm{~m}$ in 2008, 0 to $15 \mathrm{~m}$ in 2009) with a vertical haul. At the beginning and end of the drifting station, this vertical haul would be immediately followed by an oblique net tow spanning the entire water column.

\section{Cross-isobath transects}

Because of the low right whale population size, systematic habitat sampling consisting of simultaneous visual and oceanographic surveys conducted on predetermined random transects was considered extremely inefficient (i.e. very few, if any, right whales would be encountered with such a sampling design). Moreover, the logistical constraints of several competing research activities relegated the oceanographic surveys to times with very poor sighting conditions, which precluded visual sighting effort (e.g. fair weather days were reserved for tagging operations). To overcome these limitations, we conducted surveys only after we had developed a sense for the general distribution of whales in the study area so that we could choose locations for the surveys based on where we did and did not expect to encounter whales. This design was intended to facilitate comparisons of prey abundance and oceanographic conditions between areas where whales were present and areas where whales were absent. For some surveys, the center of the survey transect was located in an area where right whales were recently sighted, and extended 20 to $30 \mathrm{~km}$ to the northeast and southwest of this central location. The total length of each transect was 40 to $60 \mathrm{~km}$. A single cast with the vertical profiling instrument package was conducted at stations spaced $4.6 \mathrm{~km}$ apart along the transect. Sonobuoys were also deployed at some stations along the transects to detect the presence of right whales ( $\mathrm{n}=3$ during 2008, $\mathrm{n}=11$ during 2009).

Logistic regression was used to examine the relationship between the relative probability of right whale detection during a sonobuoy deployment and environmental conditions observed with the vertical profiling instrument package. The regression model was as follows:

$$
\ln \left(\frac{\pi}{1-\pi}\right)=\beta_{0}+\beta_{1} V
$$

where $\pi$ is the relative probability of detecting a right whale call during a sonobuoy recording, $V$ is an environmental variable, and $\beta_{0}$ and $\beta_{1}$ are model parameters. The water column was highly stratified and downward refracting, suggesting that acoustic propagation distances were relatively short. From maximum detection distances of localized calls from the drifting buoys and preliminary propagation modeling, we estimated the detection distance of right whale calls was likely $12 \mathrm{~km}$ or less (data not shown); therefore, a sonobuoy detection suggested only that a right whale was in the vicinity of a station, not actually at the station. To account for this spatial uncertainty, the value of each environmental variable associated with a sonobuoy deployment was calculated as an average of the values measured at the station where the sonobuoy was deployed and the 2 immediately adjacent stations on the transect.

\section{Tagging}

We attempted to attach archival tags to right whales for short periods of time (hours), track them closely, and sample prey distribution and oceanographic properties within tens of meters of the tagged whale's surfacing positions using the vertical profiling instrument package. During 2008, we used a suctioncup attached tag consisting of a time-depth recorder (MK9, Wildlife Computers), pitch and roll instrument (DST pitch and roll, Star-Oddi), radio transmitter (CHP-5P, Telonics), and acoustic transmitter (V22P, Vemco) that was deployed from a rigid hull inflatable boat using an $8 \mathrm{~m}$ telescoping aluminum pole (after Baumgartner \& Mate 2003). During 2009, we used a dermal attachment tag consisting of a time-depth recorder (LAT1500, Lotek), radio transmitter (MOD050, Telonics), and acoustic transmitter (V22P, Vemco) that was deployed using a compressed air launcher (Heide-Jørgensen et al. 2001). The tag was connected via a tether to the dermal attachment, a $6.5 \mathrm{~cm}$ long needle designed to anchor in the epidermis and blubber, and detachment was achieved with a corrosive foil release that allowed the tether to separate from the tag. Both the suction cup and dermal attachment tags had sufficient flotation to allow them to be recovered at the surface after detachment from the whale. During 2008, we found right whales to be quite evasive and difficult to approach in a rigid hulled inflatable boat; hence, no whales were successfully tagged in 2008. The increased deployment range afforded by the dermal attachment tag allowed a single tag to be deployed in 2009 . 


\section{RESULTS}

\section{OPC and VPR calibration}

The optimum OPC particle size range for predicting late-stage Calanus marshallae abundance was 1.95 to $2.45 \mathrm{~mm}: \mathrm{r}^{2}=0.551$ for the 2008 calibration dataset $(n=12, p=0.0057)$, RMSE of log-transformed abundances $=0.945$ for the 2009 validation dataset $(\mathrm{n}=7)$. The final calibration equation predicting $C$. marshallae abundance $\left(\mathrm{A}_{\mathrm{OPC}}\right)$ from $\mathrm{OPC}$ particle counts between 1.95 and $2.45 \mathrm{~mm}\left(\mathrm{OPC}_{1.95-2.45}\right)$ was derived from all 2008 and 2009 stations $(\mathrm{n}=19)$ and was as follows:

$\log _{10}\left(\mathrm{~A}_{\mathrm{OPC}}\right)=\left[\log _{10}\left(\mathrm{OPC}_{1.95-2.45}\right)-0.4804\right] / 0.4404$

$\left(\mathrm{r}^{2}=0.485, \mathrm{p}=0.0009 ;\right.$ Fig. 2a). As with $C$. finmarchicus (Heath et al. 1999, Baumgartner 2003), OPC particle counts underestimated net-derived $C$. marshallae abundance at moderate to high abundances (Fig. 2a). VPR-derived abundance of copepods between 1.5 and $3.5 \mathrm{~mm}$ length was strongly correlated with net-derived $C$. marshallae abundance $\left(\mathrm{r}^{2}=\right.$ $0.705, \mathrm{p}=0.0006)$; however the VPR overestimated C. marshallae abundance at low net abundances and underestimated C. marshallae abundance at high net abundances (Fig. 2b). To account for this, the following regression equation was derived from the 2008 stations only ( $\mathrm{n}=12$; there were no collocated VPR casts and net tows in 2009) and used to predict $C$. marshallae abundance $\left(\mathrm{A}_{\mathrm{VPR}}\right)$ from VPR counts of copepods of 1.5 to $3.5 \mathrm{~mm}$ length $\left(\mathrm{VPR}_{1.5-3.5}\right)$ :

$\log _{10}\left(\mathrm{~A}_{\mathrm{VPR}}\right)=\left[\log _{10}\left(\mathrm{VPR}_{1.5-3.5}\right)-1.451\right] / 0.5189$

OPC-derived C. marshallae abundance was significantly correlated with VPR-derived abundance for all stations in 2008 and $2009\left(n=62, r^{2}=0.607\right.$, $\mathrm{p}<0.0001$; Fig. 2c; stations with collocated net tows or with $\mathrm{A}_{\mathrm{VPR}}$ or $\mathrm{A}_{\mathrm{OPC}}=0$ were excluded). The median ratio of $C$. marshallae abundance estimates $\left(\mathrm{A}_{\mathrm{VPR}} / \mathrm{A}_{\mathrm{OPC}}\right)$ was 0.990 (95\% CI: 0.696-1.41), which was not significantly different from 1 (t-test of log-

Fig. 2. Calanus marshallae. Relationship between (a) optical plankton counter (OPC)-derived particle abundance and net-derived late-stage $C$. marshallae abundance, (b) video plankton recorder (VPR)-derived large copepod abundance and net-derived late-stage C. marshallae abundance, and (c) OPC- and VPR-derived C. marshallae abundance estimates. Thin gray line indicates 1:1 line, and the dashed line in (a) and (b) indicates the fitted regression line
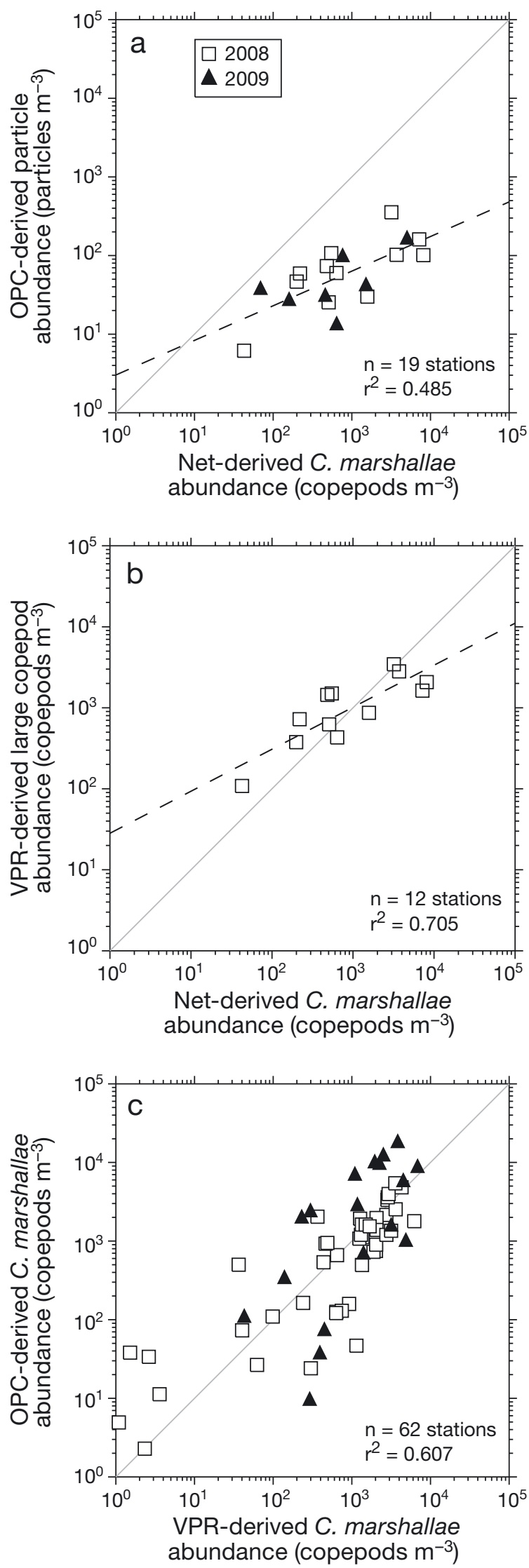
transformed differences: $t=-0.061, \mathrm{p}=0.9513)$. On average, the OPC- and VPR-derived abundance estimates agreed to within a factor of 3.96 (root mean square of log-transformed differences = $0.597)$.

\section{Zooplankton sampling}

Pseudocalanus spp. were numerically dominant in the oblique tows conducted within several kilometers of right whales (hereafter referred to as 'in proximity to' or 'near' right whales). On average, Pseudocalanus spp. were 2.4 times as abundant as Calanus marshallae ( $\mathrm{n}=7$ tows, average $C$. marshallae abundance $=751$ copepods $\mathrm{m}^{-3}$, average Pseudocalanus spp. abundance $=1404$ copepods $\mathrm{m}^{-3}$, average of $\log _{10}$-transformed abundance ratios $=0.376, \mathrm{SD}=$ $0.294, t$-test of ratio $=1: t=3.39, \mathrm{p}=0.0147$ ). However, since $C$. marshallae is a much larger copepod than Pseudocalanus spp., C. marshallae dominated the zooplankton biomass; C. marshallae biomass in proximity to right whales was, on average, 16.2 times that of Pseudocalanus spp. ( $\mathrm{n}=7$ tows, average $C$. marshallae biomass $=245.5 \mathrm{mg} \mathrm{m}^{-3}$, average Pseudocalanus spp. biomass $=11.9 \mathrm{mg} \mathrm{m}^{-3}$, average of $\log _{10^{-}}$ transformed biomass ratios $=1.21, \mathrm{SD}=0.294, t$-test of ratio $=1: t=10.9, \mathrm{p}<0.0001)$. C. marshallae was only found in developmental Stages C4 to C6 in tows conducted near right whales, and of these stages, C5 was overwhelmingly predominant (average percent contribution of C5 to all C. marshallae stages near right whales was $94.8 \%, \mathrm{SD}=6.88 \%, \mathrm{n}=7$ ). The few tows collected on the shelf with right whales absent suggested that the shelf-wide population of C. marshallae was almost exclusively in Stage C5 during the time of our study (average percent contribution of C5 to all C. marshallae stages collected with right whales absent was $95.9 \%, \mathrm{SD}=4.85 \%, \mathrm{n}=3$ ). Other copepods were present in the zooplankton net samples collected near right whales, but they either had very low abundance (e.g. Neocalanus spp.) or were too small or infrequently encountered to be an important food resource for right whales (e.g. Acartia longiremis, Oithona similis). Chaetognaths and bivalve larvae were relatively common, but abundances of these taxa were low when compared to copepods. Finally, the large jellyfish Chrysaora melanaster was extremely abundant in the region in both 2008 and 2009; several would often be caught in each zooplankton tow, and our vertical profiling instrument package would almost always return on deck with numerous jellyfish tentacles attached to it.

\section{Drifting stations}

During the 2008 drifting station study, the abundances of Calanus marshallae and Pseudocalanus spp. in the upper $10 \mathrm{~m}$ of the water column were not significantly different (on average, the ratio of Pseudocalanus spp. to $C$. marshallae was $0.93: 1$; average $\log _{10}$-transformed abundance ratio $=-0.0332, \mathrm{SD}=$ $0.224, \mathrm{n}=5, t$-test: $t=-0.332, \mathrm{p}=0.7566$; note low power of this test); however the biomass of C. marshallae was, on average, 41.5 times that of Pseudocalanus spp. (average $\log _{10}$-transformed biomass ratio $=1.62, \mathrm{SD}=0.224, \mathrm{n}=5, t$-test: $t=16.1, \mathrm{p}<$ 0.0001). Both the OPC and the VPR indicated high variability in C. marshallae abundance in the upper $10 \mathrm{~m}$ over the course of the station (Fig. 3a), with some estimated peaks in abundance exceeding 30000 copepods $\mathrm{m}^{-3}$. Although the net-derived average water column abundance of $C$. marshallae was modest at the beginning (547 copepods $\mathrm{m}^{-3}$ ) and end (482 copepods $\mathrm{m}^{-3}$ ) of the station, the OPC and VPR observations suggested that the average water column abundance rose to over 4000 copepods $\mathrm{m}^{-3}$ around the mid-point of the station (Fig. 3b). The OPC-derived distribution of C. marshallae (Fig. 3c) indicated that the vast majority of $C$. marshallae occurred in the thermocline and surface mixed layer of the upper 20 to $25 \mathrm{~m}$ of the water column, (this pattern is identical to that observed in the VPR-derived vertical distribution; data not shown). Acoustic detections from both the sonobuoys (Fig. 3c) and the drifting buoys (data not shown) indicated that right whales were present during the 2008 drifting station.

In contrast to 2008, the abundance of Pseudocalanus spp. in the upper $15 \mathrm{~m}$ of the water column during the 2009 drifting station was significantly higher than that of Calanus marshallae (on average, the ratio of Pseudocalanus spp. to C. marshallae was $11.0: 1$; average $\log _{10}$-transformed abundance ratio $=$ 1.04, $\mathrm{SD}=0.654, \mathrm{n}=5$, $t$-test: $t=3.56, \mathrm{p}=0.0236)$, and Pseudocalanus spp. biomass was not significantly different from that of C. marshallae (average $\log _{10^{-}}$ transformed biomass ratio $=0.544, \mathrm{SD}=0.654, \mathrm{n}=5$, $t$-test: $t=1.86, \mathrm{p}=0.1367$ ). While Pseudocalanus spp. net abundance was slightly higher during 2009 than 2008, both the net samples and the OPC indicated that $C$. marshallae abundance in the upper water column was much lower during the 2009 drifting station than during the 2008 drifting station (Fig. 3d). Despite these changes in the upper water column, the OPC-derived average water column abundance of C. marshallae actually peaked at over 6000 copepods $\mathrm{m}^{-3}$ (higher than in 2008) near the beginning of 

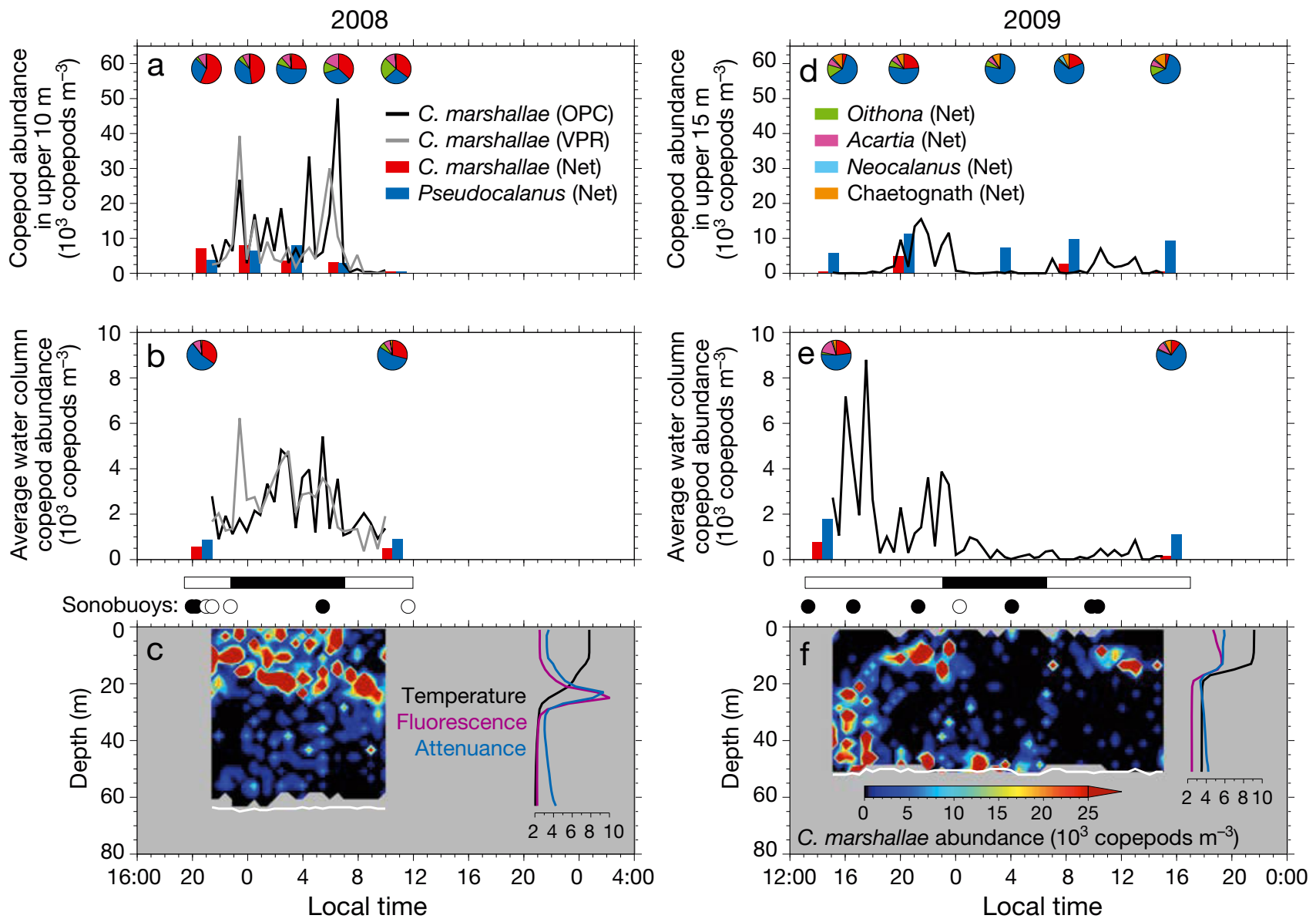

Fig. 3. Calanus marshallae, Pseudocalanus spp., and Eubalaena japonica. Copepod vertical distribution observed during the drifting stations in 2008 and 2009. (a) Average abundance of C. marshallae over the upper 10 m estimated with the optical plankton counter (OPC; black line), video plankton recorder (VPR; gray line) and net hauls (red bars), and of Pseudocalanus spp. estimated with net hauls (blue bars) for 6 and 7 August 2008. Pie charts show the zooplankton community composition at the time of each net haul. (b) Average water column abundance of $C$. marshallae and Pseudocalanus spp. during 2008. (c) Vertical distribution of C. marshallae estimated with the OPC during 2008 (sea floor indicated by the white line). Inset shows the average vertical distribution of temperature (black line in units of ${ }^{\circ} \mathrm{C}$; scale below lines), chlorophyll fluorescence (purple line in relative units), and light attenuance (blue line in relative units) over the course of each station. Day (white) and night (black) periods indicated by the bar above (c). Circles above (c) indicate sonobuoy deployments during the drifting station when right whales were acoustically detected (filled) and not detected (open). (d) Average copepod abundance over the upper $15 \mathrm{~m}$, (e) average water column abundance, and (f) vertical distribution of C. marshallae for 27 and 28 July 2009. All symbols and annotations in $(\mathrm{d}-\mathrm{f})$ identical to that in $(\mathrm{a}-\mathrm{c})$

the station (Fig. 3e). These changes between years were largely caused by a difference in the vertical distribution of C. marshallae (Fig. 3f); the OPC observations indicated that $C$. marshallae occurred throughout the water column during the 2009 drifting station, whereas C. marshallae was largely confined to the upper water column during the 2008 drifting station. As in 2008, acoustic detections from both the sonobuoys (Fig. 3f) and the drifting buoys (data not shown) indicated that right whales were present during the 2009 drifting station.

The vertical distribution of C. marshallae was not strongly related to surface chlorophyll fluorescence, an indicator of surface phytoplankton abundance. Although C. marshallae abundance during 2008 was high near the base of the thermocline where there was a persistent peak in chlorophyll fluorescence, $C$. marshallae also occurred in the upper $10 \mathrm{~m}$ where fluorescence was relatively low (Fig. 3c). During 2009, C. marshallae was not only found in the surface mixed layer where fluorescence was high, but also in the thermocline and the bottom layer (including some very near bottom patches) where fluorescence was comparatively low (Fig. 3f). Interannual differences in the vertical distribution of $C$. marshallae appeared to be associated, in part, with changes in 

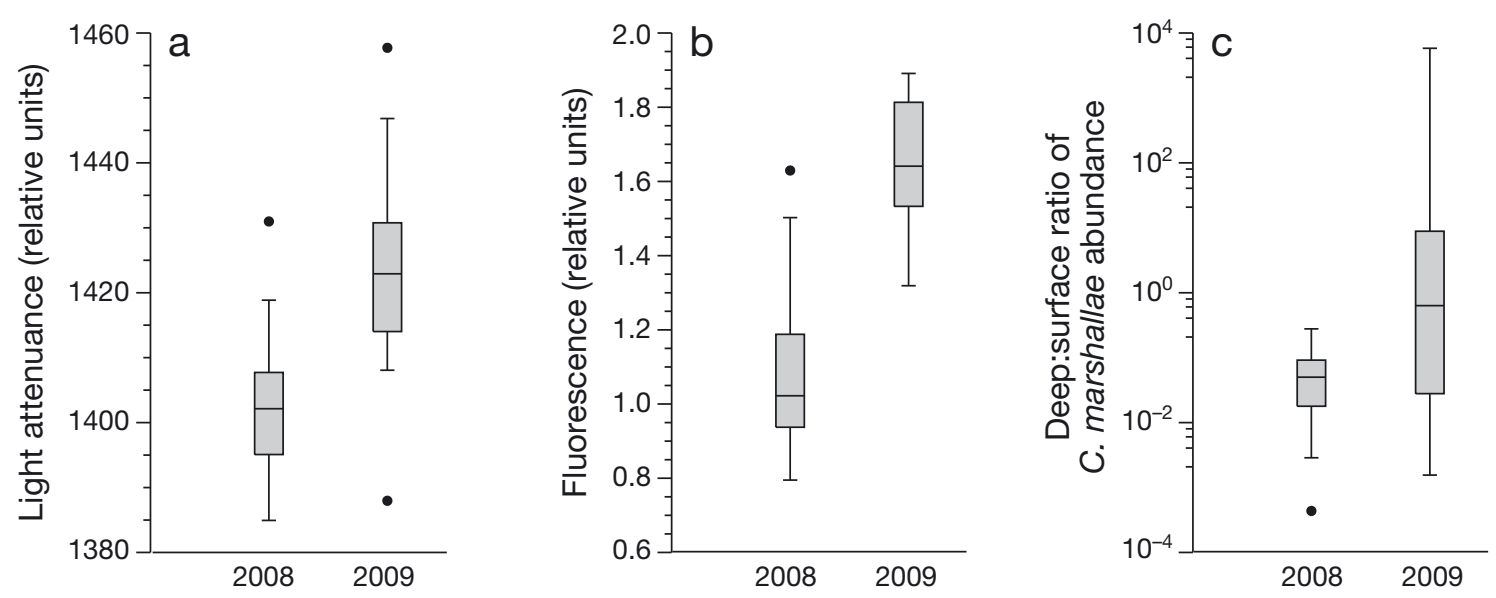

Fig. 4. Calanus marshallae. Boxplots of (a) average deep light attenuance, (b) average deep chlorophyll fluorescence, and (c) ratio of deep to surface OPC-derived C. marshallae abundance at the drifting stations for 2008 (n = 26 casts) and 2009 (n = 49 casts). Deep layer defined as $30 \mathrm{~m}$ to the sea floor, and surface layer defined as 0 to $30 \mathrm{~m}$

light attenuance and chlorophyll fluorescence in the bottom layer (i.e. from $30 \mathrm{~m}$ to the sea floor); during 2009, average light attenuance at depth was higher $(t=-7.68, \mathrm{p}<0.0001 ;$ Fig. 4a), average chlorophyll fluorescence at depth was higher $(t=-12.79, \mathrm{p}<$ 0.0001; Fig. 4b), and the deep-to-surface ratio of $C$. marshallae abundance was higher $(t=-3.90, \mathrm{p}=$ 0.0002 ; note unequal variances in Fig. $4 \mathrm{c}$; MannWhitney non-parametric test: $U=325, p=0.0005$ ) than in 2008. These observations suggest that $C$. marshallae may be more abundant near the bottom when light attenuance and chlorophyll fluorescence at depth are elevated.

\section{Cross-isobath transects}

In 2008, 2 cross-isobath transects were conducted $6 \mathrm{~d}$ apart in nearly the same location (Fig. 1b). In 2009, 3 cross-isobath transects were conducted: Transects 1 and 3 occurred $9 \mathrm{~d}$ apart in the same location as the 2 transects conducted in 2008, and Transect 2 was conducted $50 \mathrm{~km}$ to the east (Fig. 1c). As expected in the middle shelf domain during the summer, the water column was stratified into 2 layers, a warm fresh layer at the surface and a cold salty layer at depth, and these 2 layers were separated by a sharp pycnocline (Fig. 5). During 2008, a subsurface front was observed in the middle of Transects 1 and 2 as a high cross-isobath gradient in salinity (Fig. 5b,g). This front was not present during 2009, when bottom layer salinities were much less variable across the study area (Fig. 5l,q,v). Surface salinity, however, varied significantly along Transect 2 during 2009 as well as between Transects 1 and 2 and Transects 2 and 3 (Transect 1 and 3 were in the same location), indicating an intrusion of salty water in the southeast corner of the study area that formed a front (seen at $20 \mathrm{~km}$ from the start of 2009 Transect 2 in Fig. 5q).

Despite these significant gradients in salinity, the subsurface (2008) and surface (2009) fronts appeared to have little influence on the distribution and abundance of phytoplankton inferred from chlorophyll fluorescence. Patterns in chlorophyll fluorescence suggested that phytoplankton abundance varied significantly in both time and space, but with the exception of a small decrease in fluorescence on the salty side of the surface front observed on Transect 2 in 2009 (Fig. 5r), these patterns did not appear to be strongly influenced by the fronts. Fluorescence was generally highest in the pycnocline, particularly during the early to mid August transects conducted in 2008 (Fig. 5c,h). The late July transects conducted during 2009 were characterized by lower fluorescence in the pycnocline than in 2008, but comparatively higher fluorescence at depth below the pycnocline (Fig. 5m,r,w). Deep fluorescence observed during Transect 1 in 2009 was particularly high, possibly indicating a phytoplankton settling event (Fig. $5 \mathrm{~m}$ ). Similar to that observed during the drifting stations, the higher chlorophyll fluorescence at depth along Transects 2 and 3 in 2009 (Fig. 5r,w) was accompanied by both higher light attenuance (Fig. $5 \mathrm{~s}, \mathrm{x}$ ) and higher Calanus marshallae abundance (Fig. 5t,y) when compared to observations in 2008.

The fronts also appeared to have little influence on the distribution and abundance of Calanus marshallae (Fig. 5). The highest C. marshallae abundances were observed during Transects 2 and 3 in 2009 at depth (Fig. 5t,y) where there was little cross-isobath varia- 


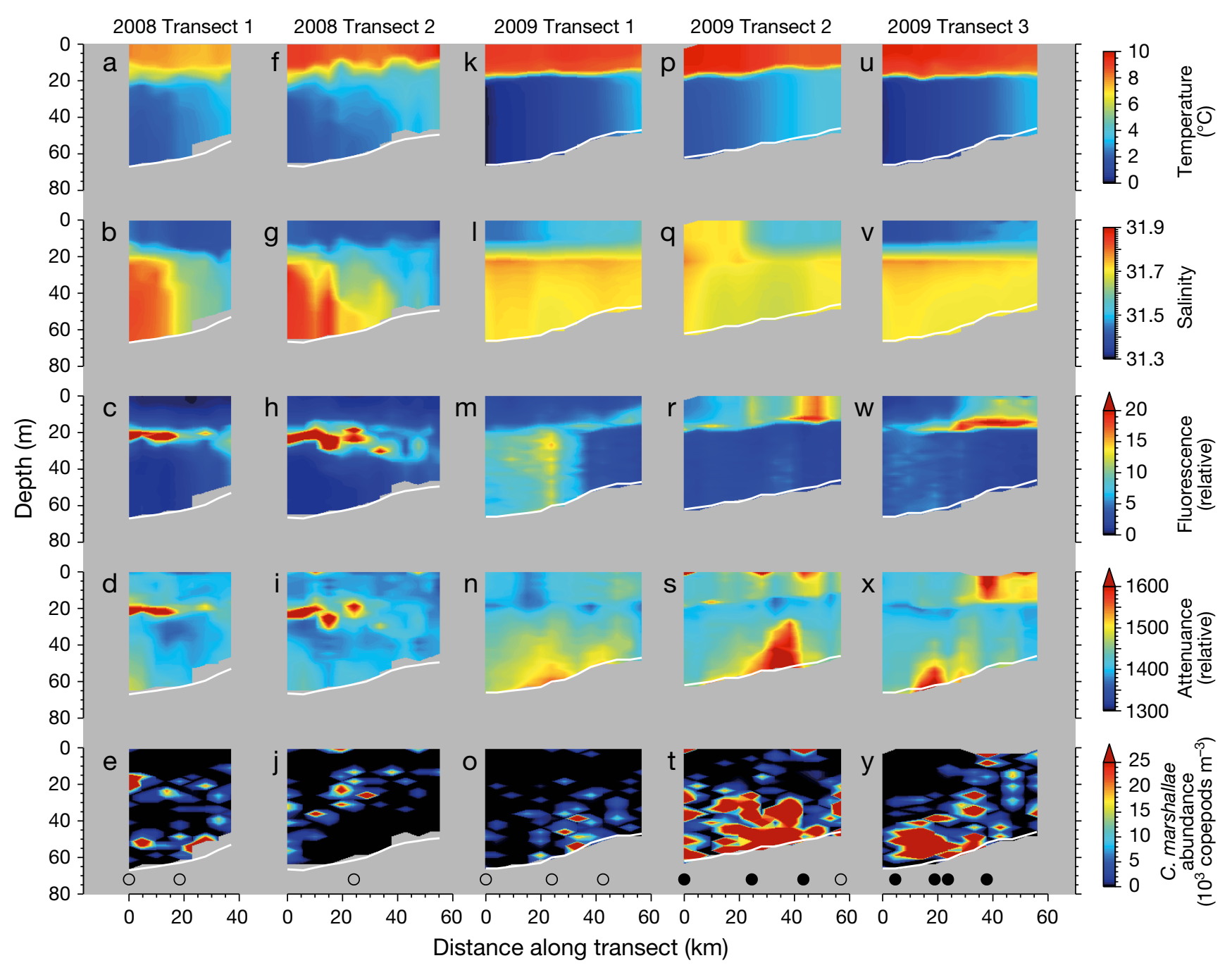

Fig. 5. Calanus marshallae and Eubalaena japonica. Cross sections of temperature, salinity, chlorophyll fluorescence, light attenuance, and OPC-derived C. marshallae abundance collected during cross-isobath transects. The origin of each transect is the most southwest station. Circles just above $x$-axis indicate sonobuoy deployments when right whales were detected (filled) and not detected (open). Note that salinity between 10 and $24 \mathrm{~m}$ during 2009 is linearly interpolated because the strong vertical gradient in temperature made accurate estimation of salinity from measured conductivity difficult

bility in hydrographic properties. C. marshallae abundance and distribution also appeared to be unaffected by the distribution and abundance of phytoplankton in the surface layer and pycnocline. Despite observing consistently high fluorescence measurements in the pycnocline, the median log-transformed C. marshallae abundances in the surface and bottom layers were never both significantly lower than that observed in the pycnocline (one-sided paired $t$-test for each transect, $\mathrm{p}>0.20$ for each). Deep C. marshallae abundance was higher during Transects 2 and 3 in 2009 when deep fluorescence and light attenuance were higher than that observed in 2008; however C. marshallae abundance was low when deep chlorophyll fluorescence was very high during Transect 1 in 2009.
Poor visibility owing to fog, heavy seas, or darkness made sighting effort impossible during the crossisobath transects, but right whale presence was acoustically monitored with sonobuoys (Figs. 5 \& 6). Right whales were not detected during the three 2008 sonobuoy deployments or along Transect 1 in 2009 when C. marshallae abundance was comparatively low (Fig. 6a-C); however, right whales were often detected along Transects 2 and 3 in 2009 when C. marshallae abundance was quite high (Fig. 6d,e). The probability of acoustically detecting a right whale with a sonobuoy was strongly related to the average water column abundance of $C$. marshallae (logistic regression, $\mathrm{p}=0.0002$ ), and the detection probability increased steeply with $C$. marshallae 

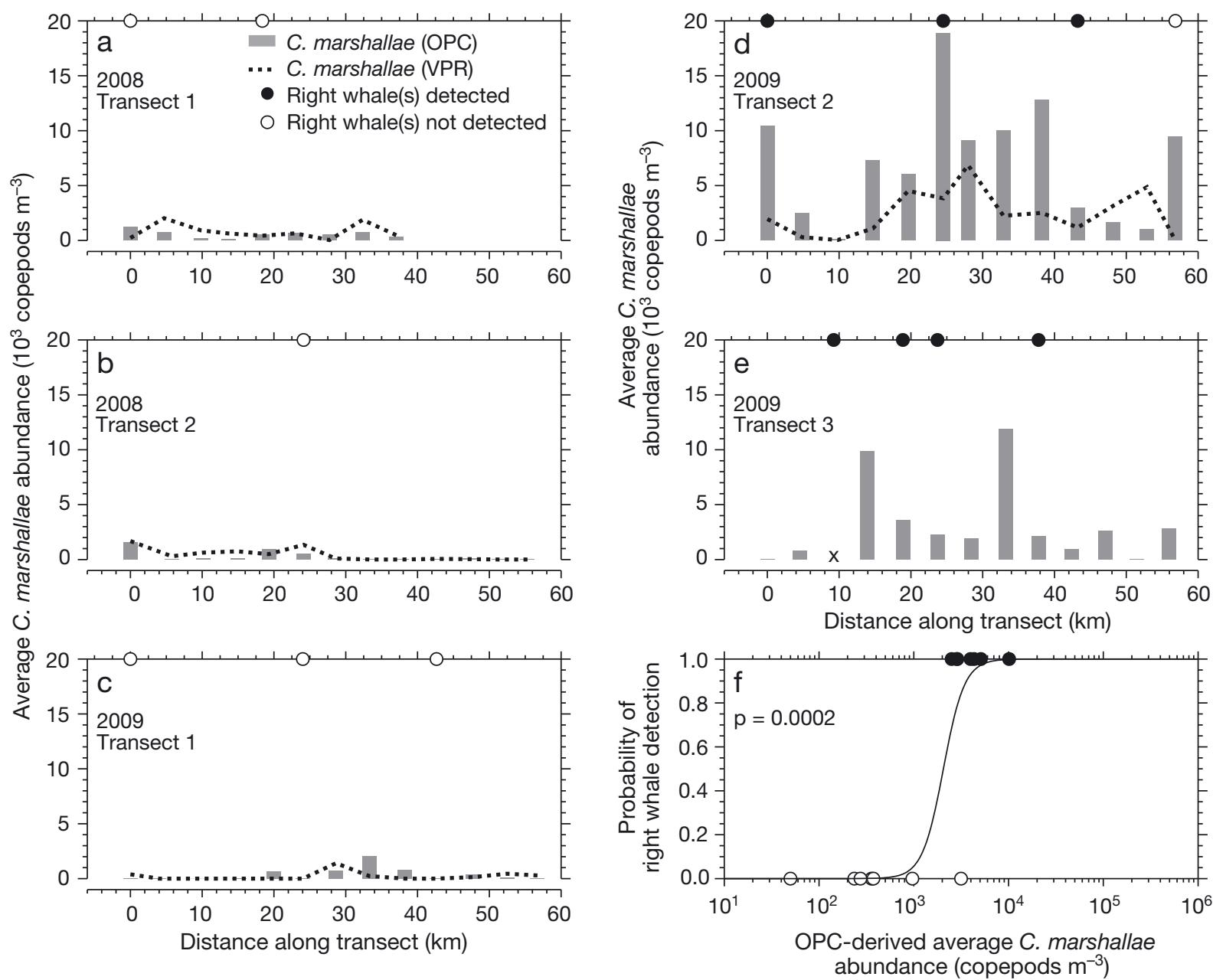

Fig. 6. Calanus marshallae and Eubalaena japonica. (a-e) Average water column abundance of C. marshallae estimated with the OPC (gray bars) and VPR (dotted line) along the cross-isobath transects. Circles indicate sonobuoy deployments during the surveys when right whales were acoustically detected (filled) and not detected (open). Stations lacking C. marshallae data are indicated with an ' $\mathrm{x}$ '. (f) Relationship between relative probability of detecting one or more right whale calls on a sonobuoy and OPC-derived average water column C. marshallae abundance. Circles on axes indicate sonobuoy deployments, and the line depicts the fitted logistic regression. The significance of the logistic regression is indicated as a p-value

abundances of 1000 to 4000 copepods $\mathrm{m}^{-3}$ (Fig. 6f). Since we detected no diel trends in calling behavior during the drifting stations (Fig. 3c,f for sonobuoys, drifting buoy data not shown), and 12 of the 14 crossisobath sonobuoys were deployed during daylight hours, we do not believe temporal patterns in calling behavior significantly influenced our assessment of right whale spatial distribution during the cross-isobath transects.

Of all the environmental variables examined, Calanus marshallae abundance had the strongest influence on the probability of detecting a right whale during a sonobuoy recording (Table 2). There was little evidence of a relationship between detection probability and any of the variables derived from temperature, salinity, or fluorescence (Table 2). Al- though the logistic regression model results for both surface layer temperature $(p=0.0033)$ and surface layer light attenuance $(p=0.0127)$ suggested a relationship, these significant results mostly captured interannual differences in surface temperature and light attenuance. When only the 2009 data were used ( $\mathrm{n}=11$ stations), the $\mathrm{p}$-values for these models became insignificant ( $p=0.0526$ for surface layer temperature, and $p=0.0990$ for surface layer light attenuance), but the results for the models with $C$. marshallae abundance remained unchanged $(\mathrm{p}=$ 0.0030 for $C$. marshallae average water column abundance, and $\mathrm{p}=0.0059$ for $C$. marshallae bottom abundance).

During 2009, Transects 1 and 3 were conducted in the exact same location $9 \mathrm{~d}$ apart. Despite few differ- 
Table 2. Logistic regression model results for each environmental variable $(\mathrm{n}=14$ stations with sonobuoy deployments); drop-in-deviance statistic and significance (p). Depth strata are as follows: surface (0 to $10 \mathrm{~m})$, pycnocline (10 to $30 \mathrm{~m}$ ), and bottom (30 $\mathrm{m}$ to the sea floor). Abundance of Calanus marshallae was estimated from the optical plankton counter. ${ }^{*} 0.05>\mathrm{p} \geq 0.01,{ }^{* *} 0.01>\mathrm{p} \geq 0.001,{ }^{* * *} \mathrm{p}<0.001$

\begin{tabular}{|c|c|c|}
\hline Environmental variable & $\begin{array}{l}\text { Drop in } \\
\text { deviance }\end{array}$ & $\mathrm{p}$ \\
\hline Surface layer temperature & $8.66^{* *}$ & 0.0033 \\
\hline Bottom layer temperature & 0.26 & 0.6109 \\
\hline Surface layer salinity & 0.60 & 0.4402 \\
\hline Bottom layer salinity & 1.04 & 0.3074 \\
\hline Surface layer fluorescence & 2.74 & 0.0981 \\
\hline Pycnocline fluorescence & 0.72 & 0.3963 \\
\hline Bottom layer fluorescence & 0.30 & 0.5831 \\
\hline $\begin{array}{l}\text { Average water column } \\
\text { fluorescence }\end{array}$ & 0.01 & 0.9089 \\
\hline Surface layer light attenuance & $6.21^{*}$ & 0.0127 \\
\hline Pycnocline light attenuance & 0.23 & 0.6292 \\
\hline Bottom layer light attenuance & 2.04 & 0.1530 \\
\hline Average light attenuance & 3.52 & 0.0608 \\
\hline $\begin{array}{l}\text { Pycnocline temperature } \\
\text { gradient }\end{array}$ & 2.86 & 0.0911 \\
\hline Pycnocline salinity gradient & 0.31 & 0.5765 \\
\hline Pycnocline density gradient & 2.41 & 0.1203 \\
\hline $\begin{array}{l}\text { C. marshallae average } \\
\text { water column abundance }\end{array}$ & $13.57^{* * *}$ & 0.0002 \\
\hline $\begin{array}{l}\text { C. marshallae surface } \\
\text { abundance }\end{array}$ & 2.29 & 0.1306 \\
\hline $\begin{array}{l}\text { C. marshallae pycnocline } \\
\text { abundance }\end{array}$ & 1.60 & 0.2055 \\
\hline $\begin{array}{l}\text { C. marshallae bottom } \\
\text { abundance }\end{array}$ & $12.48^{* * *}$ & 0.0004 \\
\hline
\end{tabular}

ences in the cross-isobath distribution of temperature and salinity, there were remarkable differences in Calanus marshallae abundance (Fig. 50,y). These changes over such a short period of time are suggestive of along-isobath advection of copepods within a water mass. Based on the similarities between $C$. marshallae distribution and abundance along Transects 2 and 3 (Fig. $5 t, y$ ), it is tempting to suggest that the copepods observed on Transect 2 were advected $50 \mathrm{~km}$ to the west over the 8 intervening days to be observed again at Transect 3 . However, temperatures and salinities near the sea floor along Transect 2 were warmer $\left(\sim 1^{\circ} \mathrm{C}\right)$ and fresher $(\sim 0.03)$ than those observed at Transect 3 , indicating Transect 2 was not likely the source of copepods for Transect 3 if the copepods remained continuously in the bottom layer (i.e. if the water mass at Transect 2 was advected to Transect 3, we would expect the 2 transects to be reasonably similar in near-bottom temperature and salinity properties).

\section{Tagging}

A single right whale was tagged on July 31, 2009. The tag remained attached for only 22 min during which the whale traveled to the south at an average speed of $9.9 \mathrm{~km} \mathrm{~h}^{-1}$ (5.4 knots). A premature rupture of the corrosive release foil caused tag detachment. Because of its moderate swimming speed, short dive times, and numerous respirations, it is very unlikely that the whale fed during the short period it was tagged. The whale remained in the surface layer except for 2 short dives to just below the thermocline (Fig. 7a). The tag data were not particularly informative, therefore we were unable to address Q4. However, the highest Calanus marshallae abundances of the entire study were observed along the tagged whale's track (Fig. 7b-d): OPC-derived average water column abundances were 57220,72410 , and 11250 copepods $\mathrm{m}^{-3}$ for each of the 3 casts conducted in proximity to the tagged whale, and maximum abundances estimated over $2.5 \mathrm{~m}$ depth strata were 1090000,950700 , and 153700 copepods $\mathrm{m}^{-3}$ (note that these abundances are extrapolations from the net-OPC calibration equation shown in Fig. 2a). Abundance maxima for C. marshallae occurred near the base of the surface layer and were coincident with the sub-surface chlorophyll fluorescence maxima (Fig. 7b-d).

\section{DISCUSSION}

Our observations indicate that Calanus marshallae is the primary prey of North Pacific right whales on the southeastern Bering Sea shelf during the summer (Q1). Evidence for this inference include the following: (1) C. marshallae dominated the net-derived zooplankton community biomass in proximity to right whales, (2) the probability of detecting right whales during the cross-isobath surveys was strongly associated with C. marshallae abundance (Q3), and (3) C. marshallae abundance in proximity to the single tagged right whale was extremely high. Adults of this copepod species are recruited in early winter and lay eggs from mid January to late March before the spring bloom (Baier \& Napp 2003). By June, the first generation reaches the later copepodid stages (C3 to C5), and the majority of the population is in the last copepodid stage (C5) by July (Smith \& Vidal 1986). Some C5 copepodids molt immediately into adults and observations by Naumenko (1979) and Smith \& Vidal (1986) suggest that these adults may spawn a second generation in June. Since North 

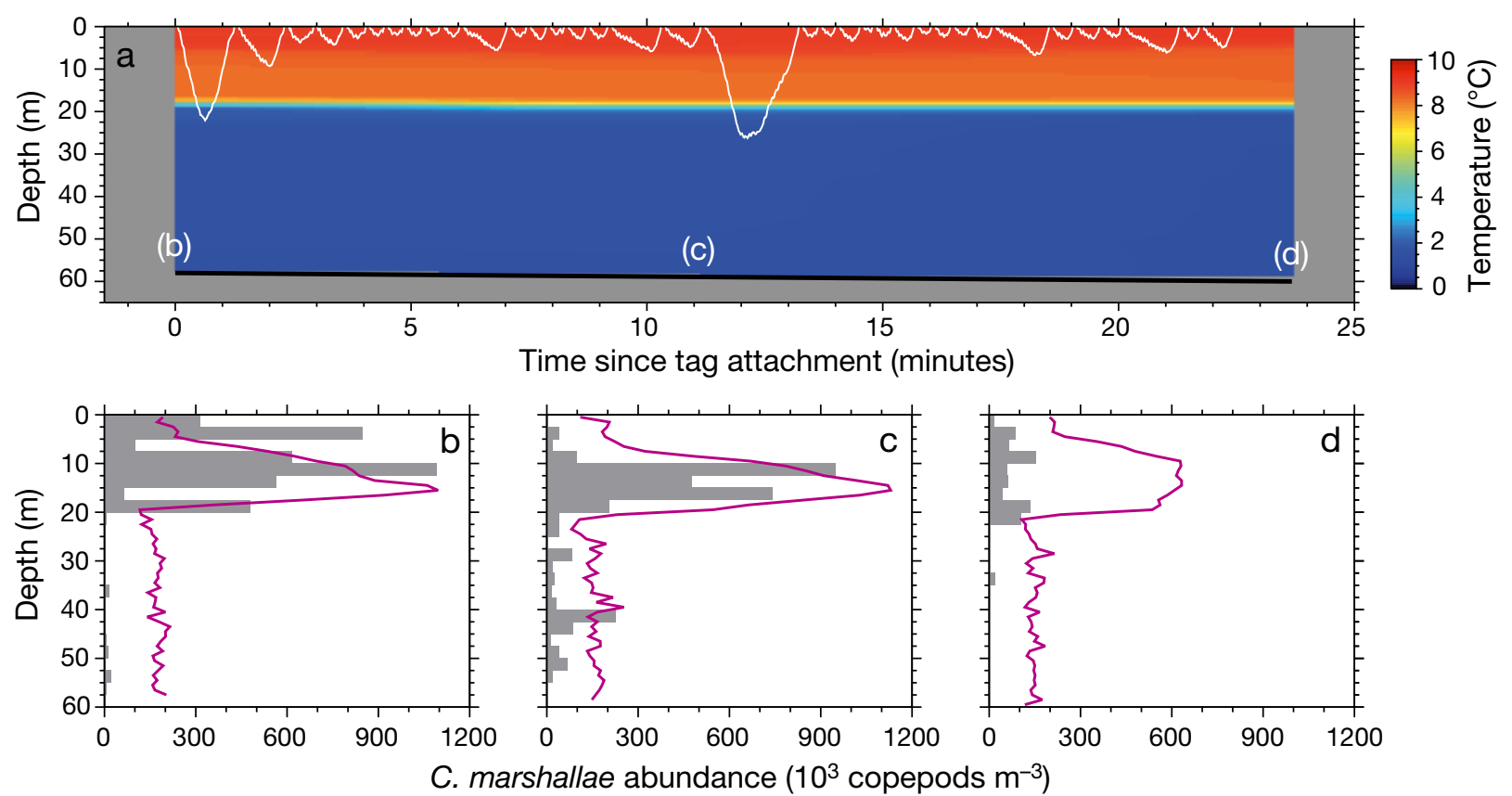

Fig. 7. Calanus marshallae and Eubalaena japonica. (a) Dive profile (white line) of the single tagged right whale shown with temperature sampled at 3 stations along the whale's swim track. The sea floor is indicated by the heavy black line. (b-d) OPCderived vertical distribution of $C$. marshallae (gray bars) and chlorophyll fluorescence (purple line in relative units) at the 3 stations along the tagged whale's swim track; each station location was chosen near the tagged whale at the corresponding time indicated just above the sea floor in (a)

Atlantic right whale baleen can begin to efficiently filter the similarly sized C. finmarchicus at around Stage C3 (Mayo et al. 2001), it is likely that the first generation of C. marshallae becomes available to North Pacific right whales sometime in June and that late-stage copepodids of both the first and second generation that are preparing for diapause remain available throughout the summer and fall. For most of the winter and spring, the C. marshallae population on the shelf probably remains in younger developmental stages that cannot be efficiently captured by right whale baleen. Because of this lack of prey as well as ice cover, the southeastern Bering Sea shelf is likely not suitable right whale habitat during the winter and spring. The seasonal occurrence of right whales inferred from acoustic detections on the southeastern Bering Sea shelf from late May to December (Munger et al. 2008) appears to closely match the seasonal development of $C$. marshallae and the availability of late-stage C. marshallae copepodids.

While Calanus marshallae is the North Pacific right whale's primary prey in the middle shelf domain of the Bering Sea, the zooplankton community that we sampled in proximity to right whales could be considered heterogeneous when compared to that of North Atlantic right whales, which is strongly dominated by $C$. finmarchicus in both abundance and bio- mass (Wishner et al. 1995, Baumgartner et al. 2003a). The relatively high abundance of Pseudocalanus spp. in the southeastern Bering Sea could represent a secondary food resource for right whales. North Atlantic right whales are regularly observed feeding on Pseudocalanus spp. in the late winter (Mayo \& Marx 1990) when the majority of the C. finmarchicus population is in the naupliar or early copepodid stages, and is therefore unavailable to be filtered by right whale baleen. It is possible that North Pacific right whales may also feed on Pseudocalanus spp. when C. marshallae is similarly unavailable over (1) annual time scales because of interannual variability in environmental conditions (Coyle et al. 2008), (2) weekly to monthly time scales because of the seasonal development of C. marshallae, or (3) hourly to daily time scales because of spatial heterogeneity in C. marshallae distribution (see below).

Very few of the larger Neocalanus spp. were observed in our zooplankton samples, which is consistent with several other studies that found that Neocalanus spp. are limited to the outer shelf domain and the continental slope (Smith \& Vidal 1986, Vidal \& Smith 1986). Smith \& Vidal (1986) observed that Neocalanus plumchrus reached the C1-C3 Stages in late April and C5 by late June in the outer shelf and slope waters. Because of their larger size, Neo- 
calanus spp. can be efficiently filtered by right whale baleen at earlier copepodid stages than C. finmarchicus or C. marshallae. Hence, right whales may be able to take advantage of Neocalanus spp. in the surface waters of the slope and outer shelf from April to June prior to the ontogenetic vertical migration and diapause of Neocalanus spp. Over the outer shelf, right whales will likely still have access to Neocalanus spp. that undergo an ontogenetic vertical migration and diapause, but are prevented from reaching great depth because of the relatively shallow depths of the outer shelf (100 to $250 \mathrm{~m}$; Wade et al. 2011b). The maximum depths to which right whales can dive and forage are unknown, since tagging studies have only been conducted on the continental shelf; therefore, the extent to which right whales can exploit diapausing copepods over the continental slope is unknown. Once Neocalanus spp. become scarce or difficult to capture in late June or early July, the middle shelf population of $C$. marshallae is in the later copepodid stages and is therefore available for right whale predation starting in June and July (Gregr \& Coyle 2009).

We found that the vertical distribution of Calanus marshallae was highly variable both between and within years (Q2). During the 2008 drifting station, $C$. marshallae was concentrated in the surface mixed layer and thermocline, and abundance was low (albeit not zero) in the cold bottom layer (Fig. 3c). The cross-isobath surveys from 2008, however, indicated C. marshallae could be found in both the thermocline and the bottom layer, but surface abundance was quite low (Fig. 5e,j). During 2009, C. marshallae occurred throughout the water column during the drifting station (Fig. 3f), was much more abundant in the bottom layer than in the thermocline or surface mixed layer during the cross-isobath surveys (Fig. 6), and was extremely abundant in the surface mixed layer in proximity to the single tagged whale (Fig. 7). There was no evidence of diel vertical migration by C. marshallae during the drifting stations (Fig. 3c,f), and while the deeper half of Transect 2 in 2009 was completed before sunset and the shallower half was completed after sunset, there was no evidence of diel vertical migration by $C$. marshallae during that survey either (Fig. 5t; all other surveys were conducted during daytime). Therefore, it is unlikely that the observed variations in C. marshallae vertical distribution were caused by diel vertical migration. Moreover, C. marshallae vertical distribution was only strongly associated with that of phytoplankton in a few instances: the drifting station in 2008 (Fig. 3c) and the single tagging event (Fig. 7). In both of these cases, C. marshallae was abundant at or above the subsurface chlorophyll fluorescence maximum.

Our observations of high Calanus marshallae abundance near the bottom in 2009 are suggestive of a diapausing stock similar to that observed for $C$. finmarchicus in North Atlantic right whale summertime feeding habitats (Baumgartner \& Mate 2003, Baumgartner et al. 2003b). However, the light attenuance and fluorescence data from the present study alternatively suggest that $C$. marshallae may actively feed on phytoplankton that have settled at the bottom and are subsequently resuspended by strong tidal currents (Fig. 5). The Bering Sea shelf is considered highly productive in part because grazing rates during the spring bloom cannot keep up with primary production rates, and much of the phytoplankton biomass sinks to the sea floor where it fuels secondary production in the benthos (Cooney \& Coyle 1982, Walsh \& McRoy 1986, Grebmeier et al. 1988, 2006). Resuspension of phytodetritus during periods of strong currents may allow pelagic zooplankton to graze at depth (Paffenhöfer \& Strickland 1970, Roman 1984). With access to this second food resource in a dark refuge, copepods would have little reason to feed near the surface where the risk of predation by visual predators (e.g. zooplanktivorous fish) is high. Yet, we did observe copepods aggregated in the surface waters and pycnocline during the 2008 drifting station (Fig. 3c) and near the tagged right whale in 2009 (Fig. 7), which may suggest that (1) there is variability in either the timing or intensity of resuspension events, (2) the risk of predation is not always high in surface waters, or (3) live phytoplankton are a much higher quality food resource than phytodetritus.

During both the drifting stations and the crossisobath surveys, we found that the abundance of Calanus marshallae was quite heterogeneous over horizontal spatial scales of kilometers to tens of kilometers. During the drifting stations, the abundance of C. marshallae changed by nearly 3 orders of magnitude in the upper 10 (2008) or $15 \mathrm{~m}$ (2009) throughout the course of our sampling (OPC-derived C. marshallae abundance in 2008: 77 to 50000 copepods $\mathrm{m}^{-3}$, in 2009: 0 to 15500 copepods $\mathrm{m}^{-3}$; Fig. 3a,d). Even the average water column abundance of C. marshallae during the 2009 drifting station varied over 3 orders of magnitude (9 to 8790 copepods $\mathrm{m}^{-3}$; Fig. 3e). We do not think that we were following the exact same patch of copepods during the drifting stations; the drifting buoys are probably not perfect current tracers, as the superstructures (i.e. top of buoy, mast, and flag) make the buoys sus- 
ceptible to wind slip, and there was certainly variability in the positioning of the vessel in the middle of the buoy array. However, we were likely sampling over a small discrete area (order 1-2 km) that advected with the currents, and we observed variability in C. marshallae abundance that was equivalent to the variability observed during the $60 \mathrm{~km}$ long cross-isobath survey transects (Figs. 5 \& 6). These observations suggest that there was significant small-scale patchiness in C. marshallae abundance at the scale of hundreds of meters to kilometers in the study area during 2008 and 2009. This patchiness appeared to be independent of any other measured changes in the water column, since temperature, salinity, and chlorophyll fluorescence were extremely stable during the course of the drifting stations (data not shown). Even over longer spatial scales, horizontal variability in C. marshallae abundance was unrelated to changes in hydrographic conditions or chlorophyll distribution (Fig. 5), even when those changes were substantial (e.g. the subsurface and surface fronts observed in 2008 and 2009, respectively).

Although we did not survey broadly over the inner, middle, and outer shelf domains of the southeastern Bering Sea, other studies have reported that right whales are frequently encountered over the middle shelf domain during the summer (Tynan et al. 2001, Shelden et al. 2005). The middle shelf domain likely attracts right whales because of its high abundance of Calanus marshallae, but it remains unclear what processes aggregate $C$. marshallae into such concentrated patches. The cross-isobath surveys were designed, in part, to investigate how gradients in hydrography may influence $C$. marshallae distribution. The subsurface front in 2008 and the surface front in 2009 appeared to have no influence on C. marshallae distribution. The gradients observed during cross-isobath Transects 1 and 3 in 2009 were very weak, indicating frontal activity over spatial scales of tens of kilometers was not responsible for the aggregations of C. marshallae in the study area. The local topography is similarly devoid of strong gradients, gently sloping at $0.35 \mathrm{~m} \mathrm{~km}^{-1}$ with no shoals or basins; therefore, it is similarly unlikely that topography has any significant influence on C. marshallae aggregations. Subtidal flow through the southeastern Bering Sea in the summer is very weak (Coachman 1986, Reed \& Stabeno 1996), but tidal currents are not in- significant. It seems clear that the usual mechanisms invoked to explain the formation of concentrated patches of copepods, namely fronts (Tynan et al. 2001) and sharp changes in topography (Gregr \& Coyle 2009), are likely not responsible for copepod aggregation in the southeastern Bering Sea (Q5).

The proposition that Calanus marshallae can feed at depth on resuspended phytodetritus offers one potential mechanism for the vertical and horizontal aggregation of copepods (Q5). We hypothesize that phytodetritus is resuspended in discrete 'clouds' (Fig. 8), and that C. marshallae in the surface waters discover these clouds while making vertical forays to near-bottom waters (not necessarily on a diel schedule). When a cloud is encountered, they remain in it to feed on the phytodetritus (or possibly on microbial phytodetritivores associated with the cloud). Since the wind-driven surface currents are faster than the currents at depth (at subtidal frequencies), there is a constantly renewed supply of copepods in the surface waters available to migrate downward and populate the cloud. Hence, C. marshallae is aggregated both vertically and horizontally in patches at depth. While this hypothesis, if correct, would help to explain our observations of high near-bottom abundances of C. marshallae, other mechanisms must be responsible for the aggregation of $C$. marshallae in near-surface waters (Figs. 3c \& 7).

In summary, Calanus marshallae is likely the primary prey of North Pacific right whales in the southeastern Bering Sea (Q1); however, we found no evidence that $C$. marshallae underwent diel vertical migration during our sampling (Q2). Right whale spatial distribution, inferred from passive acoustic monitoring, was strongly associated with the abun-

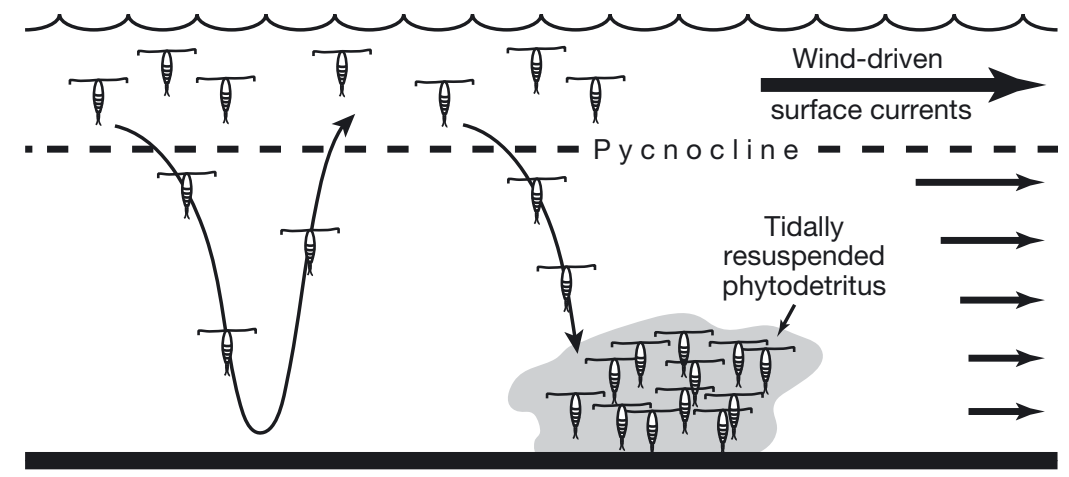

Fig. 8. Calanus marshallae. Hypothesized aggregation of C. marshallae at depth. Copepods discover and remain within discrete resuspended 'clouds' of settled phytoplankton (phytodetritus) during vertical forays from the surface layer. Because the wind-driven surface currents are faster than those at depth, a continuous supply of copepods is available in the surface layer to populate the cloud 
dance of C. marshallae (Q3). We were unfortunately unable to characterize right whale diving and foraging behavior because of our extremely limited tagging dataset (Q4). Finally, we found no evidence that fronts aggregate $C$. marshallae and thus provide feeding opportunities for right whales (Q5); instead, we hypothesize that resuspension of phytodetritus may lead to near-bottom aggregations of $C$. marshallae during the summer on the southeastern Bering Sea shelf.

Both copepod production and aggregation are extremely important processes that allow right whales to forage efficiently. The middle shelf domain of the southeastern Bering Sea clearly provides a favorable environment for the production of Calanus marshallae (Naumenko 1979, Vidal \& Smith 1986, Baier \& Napp 2003), and resuspension of phytodetritus is a potentially important mechanism for aggregating copepods. Ultimately, we believe that the availability of lipid-rich C. marshallae in the middle shelf domain during summer is the primary reason North Pacific right whales return annually to the southeastern Bering Sea.

Acknowledgements. We are grateful for assistance at sea and in the lab by B. Adams, J. Crance, A. Kennedy, D. Ljungblad, S. Mussoline, D. Reeb, F. Scattorin, S. Yin, and the late Captain Atle Remme and his outstanding crew. We are indebted to J. Leonard, T. Yost, T. Mequet, and R. Brake for providing us with surplus sonobuoys. The Atlantic Reference Centre in New Brunswick, Canada enumerated all zooplankton samples. Three anonymous reviewers provided helpful criticisms that improved the clarity and organization of the paper. This study was funded by the US Department of the Interior, Minerals Management Service (MMS; now Bureau of Ocean Energy Management), through Interagency Agreement No. M07RG13267 (AKC 063) with the US Department of Commerce, National Oceanic and Atmospheric Administration (NOAA), as part of the MMS Alaska Environmental Studies Program. Reference to trade names does not imply endorsement by the NOAA National Marine Fisheries Service. The findings and conclusions in this paper are those of the authors and do not necessarily represent the views of the NOAA National Marine Fisheries Service.

\section{LITERATURE CITED}

Baier CT, Napp JM (2003) Climate-induced variability in Calanus marshallae populations. J Plankton Res 25: 771-782

Baumgartner MF (2003) Comparisons of Calanus finmarchicus fifth copepodite abundance estimates from nets and an optical plankton counter. J Plankton Res 25:855-868

> Baumgartner MF, Mate BR (2003) Summertime foraging ecology of North Atlantic right whales. Mar Ecol Prog Ser 264:123-135

Baumgartner MF, Cole TVN, Clapham PJ, Mate BR (2003a) North Atlantic right whale habitat in the lower Bay of
Fundy and on the SW Scotian Shelf during 1999-2001. Mar Ecol Prog Ser 264:137-154

Baumgartner MF, Cole TVN, Campbell RG, Teegarden GJ, Durbin EG (2003b) Associations between North Atlantic right whales and their prey, Calanus finmarchicus, over diel and tidal time scales. Mar Ecol Prog Ser 264:155-166

Baumgartner MF, Freitag L, Partan J, Ball K, Prada K (2008) Tracking large marine predators in three dimensions: the Real-time Acoustic Tracking System. IEEE J Oceanic Eng 33:146-157

Baumgartner MF, Lysiak NSJ, Schuman C, Urban-Rich J, Wenzel FW (2011) Diel vertical migration behavior of Calanus finmarchicus and its influence on right and sei whale occurrence. Mar Ecol Prog Ser 423:167-184

Berchok CL, Morse LJ, Clapham PJ, Klinck H and others (2009) Right whale gunshot calls in the southeastern Bering Sea. J Acoust Soc Am 125:2616

Brown CW, Winn HE (1989) Relationship between the distribution pattern of right whales, Eubalaena glacialis, and satellite-derived sea surface thermal structure in the Great South Channel. Cont Shelf Res 9:247-260

Brownell RL Jr, Clapham PJ, Miyashita T, Kasuya T (2001) Conservation status of North Pacific right whales. J Cetacean Res Manag 2:269-286

Clapham P, Good C, Quinn S, Reeves RR, Scarff JE, Brownell RL Jr (2004) Distribution of North Pacific right whales (Eubalaena japonica) as shown by 19th and 20th century whaling catch and sighting records. J Cetacean Res Manag 6:1-6

> Coachman LK (1986) Circulation, water masses, and fluxes on the southeastern Bering Sea shelf. Cont Shelf Res 5: 23-108

> Cooney RT, Coyle KO (1982) Trophic implications of crossshelf copepod distributions in the southeastern Bering Sea. Mar Biol 70:187-196

Coyle KO, Pinchuk AI, Eisner LB, Napp JM (2008) Zooplankton species composition, abundance and biomass on the eastern Bering Sea shelf during summer: The potential role of water-column stability and nutrients in structuring the zooplankton community. Deep-Sea Res II 55:1775-1791

Davis CS, Gallager SM, Berman MS, Haury LR, Strickler JR (1992) The video plankton recorder (VPR): design and initial results. Arch Hydrobiol Beih Ergebn Limnol 36: 67-81

> Davis CS, Gallager SM, Marra M, Stewart WK (1996) Rapid visualization of plankton abundance and taxonomic composition using the Video Plankton Recorder. DeepSea Res II 43:1947-1970

Doroshenko NV (2000) Soviet whaling for blue, gray, bowhead and right whales in the North Pacific Ocean, 1961-1979. In: Yablokov AV, Zemsky VA (eds) Soviet whaling data (1949-1979). Center for Russian Environmental Policy, Moscow, p 96-103

> Grebmeier JM, McRoy CP, Feder HM (1988) Pelagicbenthic coupling on the shelf of the northern Bering and Chukchi Seas. I. Food supply source and benthic biomass. Mar Ecol Prog Ser 48:57-67

Grebmeier JM, Cooper LW, Feder HM, Sirenko BI (2006) Ecosystem dynamics of the Pacific-influenced Northern Bering and Chukchi Seas in the Amerasian Arctic. Prog Oceanogr 71:331-361

$>$ Gregr EJ, Coyle KO (2009) The biogeography of the North Pacific right whale (Eubalaena japonica). Prog Oceanogr 80:188-198 
Heath MR, Dunn J, Fraser JG, Hay SJ, Madden H (1999) Field calibration of the optical plankton counter with respect to Calanus finmarchicus. Fish Oceanogr 8(Suppl 1):13-24

Heide-Jørgensen MP, Kleivane L, Øien N, Laidre KL, Jensen MV (2001) A new technique for deploying satellite transmitters on baleen whales: tracking a blue whale (Balaenoptera musculus) in the North Atlantic. Mar Mamm Sci 17:949-954

$>$ Herman AW (1988) Simultaneous measurement of zooplankton and light attenuance with a new optical plankton counter. Cont Shelf Res 8:205-221

Herman AW (1992) Design and calibration of a new optical plankton counter capable of sizing small zooplankton. Deep-Sea Res 39:395-415

Ivashchenko YV, Clapham PJ (2012) Soviet catches of right whales Eubalaena japonica and bowhead whales Balaena mysticetus in the North Pacific Ocean and the Okhotsk Sea. Endang Species Res 18:201-217

> Josephson E, Smith TD, Reeves RR (2008) Historical distribution of right whales in the North Pacific. Fish Fish 9: 155-168

Kennedy AS, Salden DR, Clapham PJ (2012) First high- to low-latitude match of an eastern North Pacific right whale (Eubalaena japonica). Mar Mamm Sci 28:E539E544

Liu H, Hopcroft RR (2008) Growth and development of Pseudocalanus spp. in the northern Gulf of Alaska. J Plankton Res 30:923-935

Mayo CA, Marx MK (1990) Surface foraging behavior of the North Atlantic right whale, Eubalaena glacialis, and associated zooplankton characteristics. Can J Zool 68: 2214-2220

Mayo CA, Letcher BH, Scott S (2001) Zooplankton filtering efficiency of the baleen of a North Atlantic right whale, Eubalaena glacialis. J Cetacean Res Manag 2(Spec Issue):225-229

Munger LM, Wiggins SM, Moore SE, Hildebrand JA (2008) North Pacific right whale (Eubalaena japonica) seasonal and diel calling patterns from long-term acoustic recordings in the southeastern Bering Sea, 2000-2006. Mar Mamm Sci 24:795-814

Naumenko YA (1979) Life cycles of copepoda from the

Editorial responsibility: Per Palsbøll,

Groningen, Netherlands southeastern Bering Sea. Hydrobiol J 15:20-22

Omura H (1986) History of right whale catches in the waters around Japan. Rep Int Whaling Comm 10:35-41

> Paffenhöfer GA, Strickland JDH (1970) A note on the feeding of Calanus helgolandicus on detritus. Mar Biol 5: 97-99

> Reed RK, Stabeno PJ (1996) On the climatological mean circulation over the eastern Bering Sea shelf. Cont Shelf Res 16:1297-1305

Roman MR (1984) Utilization of detritus by the copepod, Acartia tonsa. Limnol Oceanogr 29:949-959

> Shelden KE, Moore SE, Waite JM, Wade PR, Rugh DJ (2005) Historical and current habitat use by North Pacific right whales Eubalaena japonica in the Bering Sea and Gulf of Alaska. Mammal Rev 35:129-155

Smith SL, Vidal J (1986) Variations in the distribution, abundance, and development of copepods in the southeastern Bering Sea in 1980 and 1981. Cont Shelf Res 5:215-239

Tynan CT, DeMaster DP, Peterson WP (2001) Endangered right whales on the southeastern Bering Sea shelf. Science 294:1894

Van Guelpen L, Markle DF, Duggan DJ (1982) An evaluation of accuracy, precision, and speed of several zooplankton subsampling techniques. J Cons Int Explor Mer 40:226-236.

> Vidal J, Smith SL (1986) Biomass, growth, and development of populations of herbivorous zooplankton in the southeastern Bering Sea during spring. Deep-Sea Res A 33: 523-556

Wade PR, Kennedy A, LeDuc R, Barlow J and others (2011a) The world's smallest whale population? Biol Lett 7: 83-85

Wade PR, De Robertis A, Hough KR, Booth R and others (2011b) Rare detections of North Pacific right whales in the Gulf of Alaska, with observations of their potential prey. Endang Species Res 13:99-109

> Walsh JJ, McRoy CP (1986) Ecosystem analysis in the southeastern Bering Sea. Cont Shelf Res 5:259-288

Wishner KF, Schoenherr JR, Beardsley R, Chen C (1995) Abundance, distribution and population structure of the copepod Calanus finmarchicus in a springtime right whale feeding area in the southwestern Gulf of Maine. Cont Shelf Res 15:475-507

Submitted: February 20, 2013; Accepted: June 25, 2013 Proofs received from author(s): September 4, 2013 